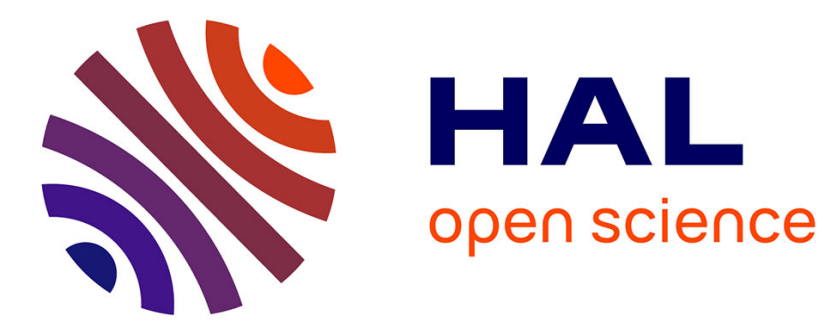

\title{
Death lines
}

Jean-Luc Moriceau

\section{To cite this version:}

Jean-Luc Moriceau. Death lines. Revue internationale de psychosociologie et de gestion des comportements organisationnels, 2017, XXIII (55), pp.193 - 204. 10.3917/rips1.055.0193 . hal-01503426

\section{HAL Id: hal-01503426 \\ https://hal.science/hal-01503426}

Submitted on 7 Apr 2017

HAL is a multi-disciplinary open access archive for the deposit and dissemination of scientific research documents, whether they are published or not. The documents may come from teaching and research institutions in France or abroad, or from public or private research centers.
L'archive ouverte pluridisciplinaire HAL, est destinée au dépôt et à la diffusion de documents scientifiques de niveau recherche, publiés ou non, émanant des établissements d'enseignement et de recherche français ou étrangers, des laboratoires publics ou privés. 
Ceci est un fichier auteur d'un article paru dans la

REVUE INTERNATIONALE DE PSYCHOSOCIOLOGIE ET DE GESTION DES

COMPORTEMENTS ORGANISATIONNELS RIPCO

Vol 23, n 1, 2007, pp. 193-204

\section{DEATH LINES}

\section{Jean-Luc Moriceau ${ }^{I}$}

\section{SUMMARY}

Approaching research as a lived experience, one quickly understands that deadlines grant research with a specific and peculiar temporality and meaning. Thanks to an autoethnographic narrative and a performative writing, the author realizes that the closer he gets to the end and the higher become his vitality, ideas, engagement, relatedness, and reflexivity. Approaching the end quickens deconstruction and reconstructions of his text, the multiplicity of ends and mournings, of traces and ghosts. A figure of research thus appears, diverging from those in epistemology, as well as a tragic parallel with existence.

Key-words: Deadline, research as practice, performative writing, autoethnography

In method books and in epistemological justification, research is supposed to unfold according to its own process, and when it is completed, to be translated and sent as a text. However, if we look at research as practice (Solé, 2007), as lived experience, from a psychosocial and organization behavior perspective, we may see a different image: research transformed and captured by the imminence of its ending, the desire of its ending, the danger of its ending.

\footnotetext{
${ }^{1}$ Jean-Luc Moriceau est professeur à l'Institut Mines-Télécom/TEM/ETHOS, il y est responsable de la formation doctorale. Ses recherches portent sur les affects, les performances et la performativité, l'écriture académique et une critique éthique et artiste du management. Il a co-édité : Demos - Philosophy, Pedagogy, Politics (Sense, 2016), L'art du sens (Eska à paraître).
} 
Indeed research is not linear but syncopated by a series of deadlines that brings in a strange and specific temporality. Especially writing, that is supposed to come at the end, is yet one of its most lively moments, however always threatened by petrification, by the end of research as process. Then, is not this intimate proximity with its end not only displaying a different temporality, but also relating research to life and to other researches, relating the researcher with the research? And would not we earn another understanding of what research is by contemplating it as a dialogue and a fight with and against its own end, its own death?

This text's writing, as a lived experience narrative in first person, will gradually be justified in the text. Description and reflexivity on experience will intertwine to present research in constant dialogue with its own ends, from which it draws creativity, situated intersubjectivity and meaning.

\section{PROSPECT OF DEATH}

I've never felt so much alive. I like those moments more than many others. My body and brain are just but one. All tensed towards this search for ideas, for expression, for comprehension. So tensed, looking for what I don't know yet, but that I feel so close to discover. For something that needs to be created, but that seems to already exist somewhere. That I am going to touch thanks to my keyboard. Time seems so short, but things go so fast, joyfully; smooth and easy. Time has the very taste of life.

What makes me so lively? The prospect of death!

Or more exactly, of a line of death. A line which is both of nascence and of death: a dead-line. A bell will ring soon, and will declare the end of the game. Beyond that bell, beyond that line, there will be no more possibility. The creation will need to be finished. Or even unfinished, always seeming unfinished, the creation will not be able to change, to move or to step back. It will be born and dead at the same moment. This line, this specific line, this dead-line, is what makes me so alive now - seizing life before ceasing life; because it is going to sentence a kind of death very soon.

What is this strange line, why so strange a time pattern? What does it mean about research? Research is given rhythm by deadlines. The time of research is a time stressed and syncopated by deadlines. And this odd temporality commands much of my research activity.

I had so much time. I had three weeks to write my research article. But I have to confess that I found so many reasons to postpone. I haven't written any line before this morning. And the lines were scarce at the beginning. Now that the deadline is approaching, the time has become denser, so creative, even burning. I regret all the lost hours before I started to write. But no, this was no lost time. Unknowingly, something started to take shape in a part of my thought. Thought is constructing over time, but the time of research is very specific. Slow, incomprehensibly slow in the beginning, and then accelerating, accelerating, towards nearly thought speed. And suddenly, thought has to stop, to freeze, to restrain itself - and the very closeness to the end is rightly what makes it so powerful and lively. 
Please, give me one more day, one more hour, ten more minutes! I haven't finished yet. I still want possibilities. And I want that the moment of creation, when I feel so right, would never cease. I am afraid of the other side, of death, of the nonreversible, of the non-amendable. I am afraid I will regret what I did not write. I am afraid of the ideas that will come afterwards, afraid that these too late ideas would be good enough, that they would have improved the text, that they would have unveiled what I really meant, to which I was so close. I am afraid of discovering I did not give all my living and loving before the deadline.

Where have all those ideas gone, that used to be so clear, and that I don't have enough time left now to recall? And I look at all those books that scream to be open and read, and of which I don't have enough time now to make friends, allies, mine... And if we had to better understand this time of research in order to really be able to read a research text? Research is made under the constraint, the pressure of time, and a time that has so strange a pattern. Bergson (1907) is certainly right when he says that we are wrong in considering time as if it was space-like. A space that we would have to fill with many activities. Research time is a time of creation. Time creates research, time creates thoughts. It guides towards the complexification of thought. And when time is over, thought freezes.

But I should chase these ideas out of my mind. Time is not over yet. I am just before, very close, nearly at the deadline, however still not yet, still not beyond. There is still a little amount of life, of possibilities. Surpassing, getting beyond where I reached, is still possible. I still strive to be surprised by what is going to come, what is still to come. I am calling what has not arrived yet, what needs to arrive very quickly. I still am desire. I am still open. I have always been astonished by how the prospect of death makes me so more alive - I dare say so more clever and lucid.

I feel far more aware, far more authentic as I feel death coming closer. Is this a kind of Heideggerian awareness?

\section{ALREADY DEAD?}

But maybe my research died a long time ago. I am trying to get the right representation of what I saw and heard on my research empirical field. But by building a model, didn't I cross another death line? Am I not freezing a multifaceted process into a single representation? Again, in this model, in this neatly arranged set of concepts, there is no more change, move or step back. No more becoming. In a model, and its wired connections, all is given (Bergson, 1934) from the outset on. Organization and research are nothing but the unfolding of a process. There is no creation.

Is it the right time to think about such considerations? I've nearly run out of time. But it is as if all that was written on my pages appeared meaningless. Irrelevant and untrue. Vain and pathetic. As if I had consumed all my time, and that the last glimmers of the candle were making me see, in a sudden and cruel clarity, what was so obviously in front of my eyes. It is a research about researching, research as practice, as lived experience, that entails passion, engagement, creativity, desires and betrayals. An activity full of affects, morale ups and downs, demands on the body. How could I 
have been so dully rational? How could I pretend to make sense if my five senses were deactivated by my sensibility? Of course rationality is required but it turns in a void if it loses sight of sensitivity. Is it possible that I bracketed and forgot all the sensuous impressions, all the emotional sensitivity, all this erotic and implicit understanding that were offered by being there, participating and being acquainted not only to facts and words, but rather to an experience? And am I doing justice to this experience with my neurotic representation?

How pretentious was I to try to perfect a work of meaning instead of casting and sending bits of senses, trying to induce movements - movements testifying that what I am studying and myself are still alive?

By wanting to reliably stick to the facts, I happened to burry all intuition and imagination. But when am I going to start thinking? When am I going to start bringing something of my own? By wanting to connect to existing theory, by wanting to ground my sayings on previous works in my research community, I may have missed the singularities and uniqueness of what I was present to. But why did I study this specific world if I am to end up with the same shapes, insights and vocabulary? If I don't change the words, the script, the plot, the masks, the focus, the connection between things and words? By wanting to triangulate, to ensure I got persistent and generalizable relations, to explain by causes and antecedents, I may have overlooked any starting of creativity and innovation, all the hesitations and trials, what is still waiting to take shape. And I've neglected to unquiet my ideas by the demands of taste, of beauty, of the sublime, of pleasure, of tragedy, of the fear of boredom.

No, I am not going to send this. It seems like a parody of research. No risk, no attempts, and nothing meaningful to aim at. I feel wretched and dispirited. And these bloody ticks of the clock as so many laughters and warnings.

But I can't afford not sending anything! Research is made of deadlines, but of pressure for publications too. I need this one more line on my assessment if I want to survive in this competitive research jungle. The deadline is definitively well named. Not only it means the death of any possibility for my work, but it can also mean the death of my research career. Publish or perish, as they say. The lines on the resume are so many blows to repel the death line a little bit farther. I will send something anyway. I felt so alive some minutes ago, and now it is as if the shadow of the Ripper was making all my moves and thoughts heavy. Again, I need to make the perspective of the death line rendering me light, meaningful, fast and concentrated. I have to play with that line of death, to gain energy and a supplement of life.

But an idea slaps my face with the brutality of evidence. And if my research even never started; would not have gone dead, but would never be born?

\section{LIVING}

I realize I sit here in my little studio, fourteen floors up, on a grey Paris night, staring at my computer screen as imploring for a quick answer. Even my notes around, my books around, are addressing a sorry smile, for not being able to help me. 
Is it possible, I think, that I have not seen, known, or said anything real and important. ${ }^{2}$ Is it possible that I have had dozens of months to look, meditate, and record, and that I have let these dozens of months slip away like a recess at school, when there is just enough time to eat your sandwich and an apple? - Yes, it is possible.

Is it possible that, in spite of the method books, in spite of culture, religion, and wisdom I tried to get from reading, I had remained at the surface of life? Is it possible that even this surface, which would at least have been something, has been covered with an incredibly dull material till it looks like salon furniture during the summer vacation? - Yes, it is possible!

And if reading books and article have distanced myself from life? I feel the need to live experiences, to be transformed, in order to start thinking. Of course I was on the field, I observed, took notes, interviewed, but I was so weary at getting the right data for my construct that I did not live those moments. It's not that I overlooked or remained blind to some aspects, it is that I feel that I have no experience. Or more exactly, that I don't let my experiences enter the research, and above all that I don't live this research as a life experience. If I am not affected, if I am not transformed, if all these experiences would not resonate with previous experiences in life, if I haven't learn to think from experience, if I haven't experienced this dance between life and thought, then what could I write?

To write a single line about researching, I need to have spent many hours of reading, doubting, not knowing what to tell, to have received many sorry smiles of colleagues and reviewers that find it premature, to have felt the anger, disgust or admiration that triggers projects, and my unreadiness and unworthiness in front of other brilliant minds. I need to have experienced the infinite energy given by love, and the pangs of separation, the betrayal of friends and the death of people that used to be so close. And as Rilke wrote, I still have to wait that these experiences transform themselves into blood inside of me, in gazes and gestures, that they lose their names and become no longer distinct from me, then I may become ready to start research, and start to write this bloody article.

Of course living, experiencing, growing transports us closer to death, put the death lines inside of us, but if it was the precondition to start writing?

\section{NO RETURN}

How could I have done that? What was I thinking about? At the bottom of the screen, the clock shows ' 00.08 '. It can't be true. No. It is too late. The deadline has passed! And I know from experience that now with the computerized submission systems, I will no longer be able to upload my article. It can't be true: so many hours of figuring out what to write, of so difficultly writing already eight pages and half, of neglecting the invitation to go out or of being with my partner, after so many excitements, readings, hopes and dreams, all is over now.

After ten minutes of incredulity, comes the time of remorse.

\footnotetext{
${ }^{2}$ The following passage intentionally paraphrases Rilke (1910). In this semi-autobiographial novel, Rilke, sitting in a small flat in Paris, reflects on death, creation, his ability to write, the meaning of writing for his life. Explanation of paraphrasing is proposed closer to the end.
} 
Having crossed the deadline, starts not only the end of possibilities, the end of creation and liveliness, but also the end of meaning. It's not enough to say that I feel disillusion, it's really an experience of a kind of death. My body, already used by the fatigue from sorrows and bad sleeps, is hardly able to move. I can just sit on my bed, a void in the gaze, with an overwhelming sadness that impedes any thought. I felt so lively one hour before, I feel so lifeless, desireless now. I hardly feel any use in breathing. Then angriness starts to work my belly, and spreads all over the body and beyond.

It's too late. I have to realize it. I need to learn from it. I need to swear I won't let such thoughts, about experience, meaning, life and death pollute my work anymore. I need to become realistic, to grow and understand that time is given by the clock, and that no thought or imagination can do something against it. There is no return.

I don't know how I manage to get asleep, but I do. And I certainly won't let any thought about the relation between sleep and death to interfere. I dreamt about a line being removed from my resume...

\section{GHOSTLY SURVIVAL}

The next morning I learn that the deadline was extended to two more days. First I felt panic. The mourning night has been very uneasy, and I did not want to go through so many emotions again. And what kind of life after am I in? Is it Hell or Paradise?

I feel inside my body and my thoughts that I am experiencing the fabrication of the academic subject. From these uneven times, these ups and downs, this flirt with death, this addiction to deadlines, theses excitements, this pride for performance, this masochistic behavior, this split from the outside world... I feel I am getting scholarized, academic-ized, transformed into a university-man. What if I, and my addictions, were nothing but a toy of the system? And how have I come to accept, even want that violence? Is it by pride, by laziness to rebel or by a kind of instinct for survival? Is this the kind of life I wanted?

But why do I take it that personally? After all, I just need to write a text. And should not the researcher keep at an objective distance, a safe distance, and write himself out of his texts? Then should not I take an eraser and delete myself of my research (Solé, 2004)? Should not I start at last to speak from a universal 'we', and squeeze myself into the standard academic text format? Here is the rub: research materializes in the text, the text grants it a body. This very text, that again is supposed to come at the end, is where and when research is granted a material presence, where and when it comes to existence. Research is text all the way through. Even in the natural sciences, as Latour (1979) as pointed out, research is triggered by texts, it is discussion and writing of texts. Even in the disciplines so careful to maintain the otherness of their objects of study, such as ethnography, it has long been recognized that research is the production of texts by an author, and that representation is before all an invention (e.g. Clifford, 1986), where theory is inextricably intertwined with writing style (Geertz, 1988; Van Maanen, 1995). Text is the body of research. And all 
bodies have a finitude. They get born, grow, mature, and die, possibly survive after death as ghosts, as traces in other texts or other lives.

I am starting to realize why I was finding so hard to write this bloody text. I was trying to cut my text off from any personal input, from any affect, from anything I might have learnt from life, from all the traces I could leave across the lines - how then could it have born some meaning (Bochner, 2001)? And probably, at some other times, I was wanting to invent a fully original text, sanitizing it from all the traces let by other texts and encounters. Those traces are what relate the text, and then the research, to life and to the whole world of texts. Those traces come from my experiences, my readings, my thoughts, but they are not purely subjective. They run through me. Others run through similar experiences, of course with difference and repetitions. Those traces are intersubjectives, and that is why they are understandable. They connect research to the life world, and to the research world. Such relatedness is what keeps our texts' meaningfulness.

Oups, again I feel swept by a swirl of doubts and hesitations. I feel the urge to pour in my experience, to draw on my affects, to explain how this research has transformed my thinking; and at the same time to recognize that these experiences happened to me, those affects occurred to me, these ideas of mine come from reading others. And at the minute I try to write, I need to acknowledge that my language is inherited, that my phrases were already used by other writers. I cannot do as if I had not read Barthes (1977), Foucault (1969) and Derrida (1988), and their compelling arguments towards the death of the author, the end of me as the creator of my lines. Another end, another death, another becoming-specter. All the more killing that this is me that has to hit the keyboard and put one character after the other to get a text ready to be sent.

Maybe it is far easiest in this way. If I could manage to mourn this navelgazing will to be an author, a pure creator, the very beginning of something; if I could simply try and attend to, describe and reflect on those experiences, affects, ideas that have come to me; if I could gratefully make use of linguistic arts passed on by predecessors; if I could keep my ego on the back seat, then writing would probably come less painfully, and more truthfully. Using criteria against myself (Bochner, 2000), I could just write from such a situated subjectivity (Burke, 1998).

Yes, if I could try to write just before all these ends: end of time, end of onlyrationality-and-objectivity-are-allowed, end of pure authorship claim, end of stick-inthe-format-or-die, end of publish and perish, etc... I would write a text as a performance rather than a representation, to make the reader feel what it is to research with deadlines, with multiple death lines. I would write a text giving to think that the repetition of an imposed and overused format grants the text with a structure far more superficial than other more profound and decisive structures that need to be understood - because the latter, and not the former, confer academic interest. I would argue that we need more than one language. I would admit that sometimes I am just repeating what others have said. I would unashamedly leave traces of the many external influences in the text, some explicit others not. And if I dared, I would use Jacques Derrida's work (e.g. 1967a, 1967b, 1994) as theoretical frame, including his concepts of writing, traces, ghost, etc. And I would use my own experience as a 
method to inquire about research as practice. I would use this vulnerable experience of mine, yet trying to fight against the ego, and knowing that getting it right is always differed. But as much of the things that matter, and to make it possible, this realization would always come at the end, just before ending.

\section{EVER CLOSER TO THE END}

I realize that the closer I get to the end, the higher I feel a kind of desire. A desire for meaning, for experience, for being and becoming. A desire for a better life, a truer life, a more authentic one. And I wish something could move inside my certitudes. I want to start to lose ground from the sure thoughts that were passed on to me by reference books and common knowledge, to shake the overused theoretical frameworks populating our reviews. It is as if I was trying to become a man, a thinker. I have certainly not started to think. I feel I am just giving the first trials and I will be exhausted before any exhaustion of meaning. I am still intimidated by the great books all over the bookshelves and now all over my carpet, and by the daring propositions of thoughts by some colleagues. But I need to stop that and start to dare some bits: the deadline is approaching again; and soon it will be too late.

But I have time. Something like 36 hours before the deadline will whistle the end of the game. I don't feel any urge for hurrying. No, I know that I am back to my good terrestrial life. And it's good to feel my body, to breathe, to jump up in the air, to sing. Good to hear even the too loud music of the neighbors and see the piles of plate in need of washing.

At some time, I see my face in the mirror. I notice all those grey hair on the sides of my head, and the lines on the sides of my eyes and mouth. I say to myself: "some people accuse me of wrongly bringing my subjectivity into my research. It's worse! In fact, it's a part of my existence that I am investing in my research." Let it be, before I cross the line of death. 


\section{BIBLIOGRAPHIE}

Barthes, R. 1967. The Death of the Author. In S. Heath, Image-Music-text: 142-148. Hammersmith, London: Fontana Press, 1967.

Bergson, H. 1907. Creative Evolution, New York: henry Hold \& Company (1911).

Bergson, H. 1934. The Creative Mind: An Introduction to Metaphysics. Mineola, NY: Dover Publications (2010)

Bochner, A. P. 2001. Narrative's Virtues. Qualitative Inquiry, 7 (2): 131-157.

Bochner, A. P. 2000. Criteria Against Ourselves. Qualitative Inquiry, 6 (2): 266-272.

Burke, S. 1998. The Death and return of the Author. Criticism and Subjectivity in Barthes, Foucault and Derrida ( $2^{\text {nd }}$ ed.). Edinburgh, Edinburg University Press.

Clifford, J. 1986. Introduction: Partial Truths. In J. Clifford \& G.E. Marcus, Writing Culture: The Poetics and Politics of Ethnography: 1-26. Berkeley: University of California Press.

Derrida, J. 1994. Specters of Marx: The Sate of the Debt, the Work of Mourning and the New International. New York: Routledge.

Derrida, J. 1988, Like the Sound of a Sea Deep within a Shell: Paul de Man's war. Critical Inquiry, 12 (3): 590-652.

Derrida, J. 1967a, Of Grammatology, Baltimore, Johns HopkinsUniversity Press (1976).

Derrida, J. 1967b, Writing and Difference, London, Routledge (1981).

Foucault, M. What is an author? In J.D. Faubion, Aesthetics, Methods, and Epistemology: 205-222. New York: The new Press, 1998

Geertz, C. 1988. Works and Lives: The Anthropologist as Author. Stanford: Stanford University Press.

Latour, B. 1979. Laboratory Life: The Social Construction of Scientific Facts. Beverly Hills, Sage Publications.

Rilke, R.M. 1910, The Notebooks of Malte Laurids Brigge, New York: W.W. Norton and co (1992).

Solé, A. 2007. Le Chercheur au travail. In A.-C. Martinet, Sciences du management : épistémique, pragmatique et éthique: 285-305. Paris, Fnege/Vuibert.

Van Maanen, J. 1995. Style as Theory. Organization Science. 6 (1) : 133- 143. 